M. B. Mirza (Aligarh); Vice-Presidents, Dr. G. S. Thapar (Lucknow) and Dr. H. D. Srivastava (Izatnagar); Chief Editor, Dr. G. S. Thapar (Lucknow); Honorary Secretary and Treasurer, Dr. B. S. Chauhan (Zoological Survey of India, 34 Chittaranjan Avenue, Calcutta 12) ; Foreign Secretary, Miss N. G. Sproston (Mandapam, Camp); and Business Manager, Dr. Kr. S. Singh (Lucknow). At the meeting it was decided to draw up a scheme for a National Parasitological Laboratory in India, and a committee of four was appointed with Dr. Thapar as president and Dr. Chauhan as secretary.

\section{University of London}

THE following appointments in the University of London have been announced: Prof. E. M. Glaser, professor of physiology in the University of Malaya, to the University readership in physiology tenable at the London Hospital Medical College ; Dr. B. C. L. Weedon, lecturer in organic chemistry at the Imperial College of Science and Technology, to the University readership in organic chemistry tenable at that College. The title of professor of genetics in the University of London has been conferred on Dr. Hans Grüneberg, in respect of his post at University College.

\section{The Night Sky in May}

New moon occurs on May 10d. 13h. 04m., U.T., and full moon on May 24d. 15h. 26m. The following conjunctions with the Moon take place: May 3d. $04 \mathrm{~h} .$, Mars $7^{\circ}$ S. ; May 1ld. 20h., Mercury $2^{\circ}$ N. ; May 13d. 13h., Venus $6^{\circ}$ N. ; May 17d. 03h., Jupiter $7^{\circ}$ N. ; May 24d. 09h., Saturn $3^{\circ}$ N. Mercury sets at $21 \mathrm{~h} .30 \mathrm{~m}$. and $21 \mathrm{~h}$. $05 \mathrm{~m}$. on May 1 and 15 , respectively, but after this draws too close to the Sun for favourable observation; its stellar magnitude is $\mathbf{0 . 3}$ and 2 at the beginning and middle of the month, respectively, the decrease in brightness being due to the decrease in the visible portion of the illuminated disk from 0.450 to 0.098 . Venus sets at $23 \mathrm{~h} .45 \mathrm{~m}$., $23 \mathrm{~h} .30 \mathrm{~m}$. and $22 \mathrm{~h}$. $35 \mathrm{~m}$. on May 1,15 and 31 , respectively. Its stellar magnitude remains almost $-4 \cdot 2$ throughout the month, although the visible portion of its illuminated disk decreases from $0 \cdot 400$ to $0 \cdot 140$; this constant magnitude is due to the fact that its distance from the Earth decreases from 98 to 77 million miles, the decreasing distance almost balancing the decreased portion of the illuminated disk. Mars rises in the early morning hours, at $2 \mathrm{~h}$., $1 \mathrm{~h} .30 \mathrm{~m}$. and $0 \mathrm{~h}$. $50 \mathrm{~m}$. at the beginning, middle and end of the month, respectively; it is close to $\theta$ Capricorni on May 3, and its eastward motion is easily noticed by comparing its positions with this star over a few nights. Jupiter, visible throughout the night, sets in the early morning hours, at $2 \mathrm{~h} .20 \mathrm{~m}$., $1 \mathrm{~h} .30 \mathrm{~m}$. and $0 \mathrm{~h} .30 \mathrm{~m}$. on May 1,15 and 31 , respectively, and is conspicuous in the constellation Leo. Saturn rises at $21 \mathrm{~h}$, $20 \mathrm{~h}$. and $18 \mathrm{~h} .45 \mathrm{~m}$. at the beginning, middle and end of the month, respectively, setting in the early morning hours; it lies rather low in the constellation Scorpius but is easily recognized, its stellar magnitude remaining 0.3 throughout the month. No occultations of stars brighter than magnitude 6 occur in May. The $\eta$-Aquarid meteors are active in the first week of the month. There will be a partial eclipse of the Moon on May 24, invisible at Greenwich but visible in Australasia ; the end will be visible in South Africa. The Moon enters the umbra at 13h. $48 \cdot 7 \mathrm{~m}$. and leaves it at $17 \mathrm{~h} .13 \cdot 8 \mathrm{~m}$.

\section{Announcements}

Tre Twentieth International Physiological Congress, organized by the Belgian Society of Physiology under the auspices of the International Union of Physiological Sciences, will be held in Brussels during July 30-August 4. An international meeting of pharmacology will be held during the Congress. Further information can be obtained from the secretary of the Congress, Prof. J. J. Reuse, Faculté de Médecine, 115 Boulevard de Waterloo, Brussels.

The eighth of the annual symposia on "Phytopharmacie et de Phytiatrie" will be held in the State Agricultural Institute, Ghent, during May 7-8. Further information can be obtained from the Secretary of the Symposium at the Rijkslandbouwhogeschool, Coupure Links 233, Ghent.

THE laboratories and technological sheds of the British Rayon Research Association, Heald Green Laboratories, Wythenshawe, Manchester 22, will be open to visitors on May 10 and 11 . There will also be a special open day for textile teachers on July 6, when Mr. L. Gibson and Dr. A. S. Roberts will speak on "Direct Spinning on the Stains Machine", and Dr. J. Mann on "Recent Researches on the Fine Structure of Cellulose".

The Institute of Personnel Management and the National Institute of Industrial Psychology are jointly arranging a five-day course on "The Use of Statistics in Personnel Management", to be held during May 14-18 in the latter body's headquarters at 14 Welbeck Street, London, W.1. The course is designed for personnel officers and others with no previous training in the use of statistical methods and their application to personnel administration. The fee for the course is ten guineas. Registration forms and further information can be obtrined from the Courses Secretary, Institute of Personnel Management, Management House, 8 Hill Street, London, W.I.

THe Bourke Lectures of the Faraday Society for 1956 will be given by Prof. J. J. Hermans, of the Laboratory of Inorganic and Physical Chemistry, University of Leyden, as follows : May 1, the physical properties of polymer solutions (at $5.15 \mathrm{p.m}$. in the Physical Chemistry Lecture Theatre, Imperial College of Science and Technology, London); May 3, poly. electrolytes (at 4.30 p.m. in the Chemistry Department, University of Birmingham); May 4, light scattering by solutions (at $5 \mathrm{p} . \mathrm{m}$. in the Nicholson Lecture Theatre, University of Liverpool). The lectures will be open to the public, without ticket. Further information can be obtained from the Faraday Society, 6 Gray's Inn Square, London, W.C.1.

THE firm of Shell Austria, A.G., has established two scholarships, each worth about $£ 70$ a year, for the study of chemistry or some allied technical subject for six years at an Austrian university. Two more scholarships will be awarded each year so that, from 1960 onwards, there will always be twelve such Shell students. The selection of candidates will be made by Shell in close collaboration with the Austrian Ministry of Education.

ErRatum. In the communication entitled "Influence of a Magnetic Field on Thermal Convection Patterns", by W. C. Levengood, in Nature of March 31, p. 631, the lower part of Fig. 2 has been reversed. 